\title{
Formation of L-Asparaginase by Fusarium Species
}

\author{
By K. NAKAHAMA, A. IMADA, S. IGARASI \\ Microbiological Research Laboratories, Central Research Division, \\ Takeda Chemical Industries, Juso, Osaka, Japan \\ AND K. TUBAKI \\ Institute for Fermentation, Juso, Osaka, Japan
}

(Received I4 September 1972)

\begin{abstract}
SUMMARY
L-Asparaginase was formed in the culture filtrates of a number of Fusarium species, as well as in those of ascomycetous fungi having a Fusarium imperfect state, such as species of Hypomyces and Nectria. Species of Gibberella, though having a Fusarium state, formed little L-asparaginase. The distribution of the ability to form the enzyme was related to taxonomic position.
\end{abstract}

\section{INTRODUCTION}

Occurrence of L-asparaginases (L-asparagine amidohydrolase, EC. 3.5.I.I) in fungi, yeasts, bacteria and animal cells, and their antitumour effects were reviewed by Adamson \& Fabro (1968) and Wriston (197I). With respect to the occurrence of L-asparaginase in fungi, Dox as early as 1909 found the activity in Penicillium camemberti. In 1928 and I930, L-asparaginase of Aspergillus niger was studied by Bach and Schmalfuss \& Mothes. Recently, DeAngeli et al. (1970) reported on L-asparaginase of A. terreus; the enzyme suppressed the growth of Walker 256 ascites sarcoma in rats. Scheetz, Whelan \& Wriston (I97I) studied the properties of L-asparaginase purified from mycelia of Fusarium tricinctum, and pointed out the inability of the enzyme to suppress the growth of $6 \mathrm{C}_{3} \mathrm{HED}$ lymphosarcoma in mice. Arima, Sakamoto, Araki \& Tamura (1972) examined the extracellular formation of L-asparaginase by a variety of micro-organisms and indicated that the enzyme was produced by several species of Penicillium, Aspergillus, and Nectria. We have studied the distribution of L-asparaginases among micro-organisms and have found them in Ascomycetes and Fungi Imperfecti as well as in bacteria and yeasts (Imada, Nakahama, Igarasi \& Isono, 1973). In that study we noticed that a large proportion of Fusarium species produced extracellular $\mathrm{L}$-asparaginase. In the present report, studies on the distribution of $\mathrm{L}$-asparaginase in species of the genus Fusarium and in related genera have been undertaken to investigate further the correlation between the distribution of enzyme activities and the classification of microorganisms.

\section{METHODS}

Organisms. All the fungal strains used in the present experiments were cultures held at the Institute for Fermentation, Osaka, Japan.

Cultivation. Fungal strains were grown on agar slants of $\mathrm{M}$ medium ( $\mathrm{pH} \mathrm{6.0)}$ which contained (g/1 distilled water): sucrose, 30; Polypepton (Daigo Nutritive Chemicals, Osaka, Japan), 5; beef extract (Wako Pure Chemicals, Osaka, Japan), 2; yeast extract (Difco 
Table I. L-Asparaginase formation by Fusarium species after 3 and 5 days of culture

Strain

Fusarium anguioides IFO4467

F. caucasicum IFO5979

F. culmorum IFO5902

F. culmorum IFo6814

F. oxysporum $\mathrm{IFO} 5942$

F. oxysporum $\mathrm{IFO} 7152$

F. oxysporum $\mathrm{IFO} 7 \mathrm{I} 55$

F. oxysporum IFO7I 56

F. oxysporum 1 FO7I 57

F. oxysporum IFO7190

F. oxysporum IFO5264

F. oxysporum IFO933I

F. oxysporum f. batatas IFO 4468

$F$. oxysporum $\mathrm{f}$. conglutinans IFO 6383

F. oxysporum f. cucumerinum IFO 6384

$F$. oxysporum f. gladioli IFO5894

$F$. oxysporum f. gladioli IFO 166

$F$. oxysporum f. lini IFO5880

$F$. oxysporum f. lini IFO 5885

F. oxysporum f. lycopersici IFO590 I

$F$. oxysporum f. lycopersici IFo653 I

$F$. oxysporum f. melongenae IFo7706

F. oxysporum f. melonis Iro6 385

$F$. oxysporum f. narcissi IFO5265

F. oxysporum f. nicotianae IF06386

F. oxysporum f. niveum IFO447I

$F$. oxysporum f. vasinfectum IFO 4472

$F$. oxysporum f. vasinfectum $\mathrm{IFO} 5903$

$F$. roseum IFO850I

F. roseum IFO8502

F. roseum $\mathrm{IFO} 8503$

F. roseum IFO542I

F. solani $\mathrm{IFO} 5232$

F. solani IFO5890

$F$. solani $\mathrm{IFO} 589 \mathrm{I}$

F. solani IFO5892

F. solani IFO 5893

F. solani IFO 5899

$F$. solani $\mathrm{IFO} 5977$

F. solani IFO7I 53

F. solani IFO7I 54

F. solani IFO7I 63

F. solani $1 \mathrm{FO} 7 \mathrm{I} 64$

F. solani IF08505

F. solani $\mathrm{IFO} 506$

F. solani $\mathrm{IFO} 8508$

$F$. solani $\mathrm{IFO} 509$

$F$. solari 1 IFO85IO

F. solani f. phaseoli IFO5978

F. solani var. martii IFO5900
Activity (i.u./ml)

\begin{tabular}{|c|c|}
\hline 3-day & 5 -day \\
\hline 0.46 & 0.15 \\
\hline 0.65 & 2.03 \\
\hline 0.55 & 0.62 \\
\hline 0.09 & 0.08 \\
\hline 0.14 & 0.31 \\
\hline 0 & 0.23 \\
\hline 0.37 & 0.08 \\
\hline 0.51 & 0.23 \\
\hline 0.19 & 0.08 \\
\hline 0 & $0.3 \mathrm{I}$ \\
\hline 2.59 & 2.95 \\
\hline $\mathrm{I} \cdot 94$ & $2 \cdot 50$ \\
\hline 0.14 & 0.23 \\
\hline 0.19 & 0.08 \\
\hline 0.19 & 0.08 \\
\hline 0 & 0.39 \\
\hline 0.23 & 0.15 \\
\hline 0.19 & $2 \cdot 85$ \\
\hline 0 & 0.23 \\
\hline 0.37 & 0.85 \\
\hline 0.32 & 0.23 \\
\hline 0 & 0.08 \\
\hline 0 & 0.08 \\
\hline 2.77 & $0.3 \mathrm{I}$ \\
\hline 0.14 & 0.62 \\
\hline$I \cdot I 5$ & 0.08 \\
\hline$I \cdot I I$ & 0.15 \\
\hline 0.23 & 0.23 \\
\hline 0.74 & 0.15 \\
\hline 0 & 0.39 \\
\hline 0.23 & 0.08 \\
\hline 3.23 & 3.14 \\
\hline 0 & $\mathrm{I} \cdot 54$ \\
\hline 0.32 & 0.62 \\
\hline 0 & 0.54 \\
\hline $\mathrm{I} \cdot 89$ & 0.46 \\
\hline 0.72 & $1 \cdot 30$ \\
\hline$I \cdot 52$ & I.69 \\
\hline 0.05 & 2.39 \\
\hline $\mathrm{I} \cdot \mathrm{OI}$ & 0.62 \\
\hline $2 \cdot 2 \mathrm{I}$ & 3.14 \\
\hline I. 48 & $2 \cdot 46$ \\
\hline $1 \cdot 20$ & $I \cdot 15$ \\
\hline I'II I & $I \cdot 3 I$ \\
\hline 0.61 & 0.54 \\
\hline 0 & $\mathrm{I} \cdot 77$ \\
\hline 0.19 & 0.15 \\
\hline $2 \cdot 91$ & 3.14 \\
\hline 0.32 & 0.08 \\
\hline 0.51 & 1.62 \\
\hline
\end{tabular}


Table 2. L-Asparaginase formation by Hypomyces species after 3 and 5 days of culture

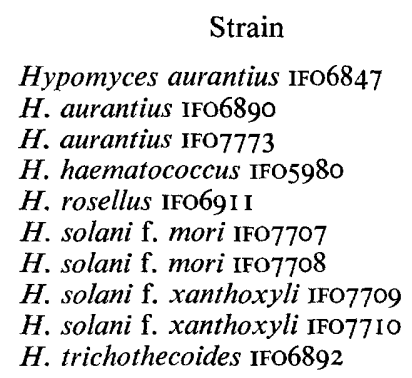

$\begin{array}{cc}\text { 3-day } & \text { 5-day } \\ 0.02 & 0.02 \\ 0.05 & 0.05 \\ 0 & 0.02 \\ 0.88 & 0.88 \\ 0.02 & 0 \\ 1.89 & 1.75 \\ 0.52 & 1.38 \\ 0.32 & 0.41 \\ 0.69 & 0.97 \\ 0 & 0.02\end{array}$

Laboratories, Detroit, Michigan, U.S.A.), 5; malt extract (Difco Laboratories), 2. Single, approximately 5 to $10 \mathrm{~mm}^{2}$, pieces of mycelial mat were inoculated into $50 \mathrm{ml}$ of DP medium in $300 \mathrm{ml}$ shaking flasks. DP medium ( $\mathrm{pH} \mathrm{6.0)} \mathrm{contained} \mathrm{(} \mathrm{g} / \mathrm{l}$ distilled water): dextrin, 30; Pharmamedia (Traders Mill Co., Fort Worth, Texas, U.S.A.), 40; $\mathrm{KH}_{2} \mathrm{PO}_{4}$, $5 ; \mathrm{K}_{2} \mathrm{HPO}_{4}, \mathrm{I} \cdot 5 ; \mathrm{MgSO}_{4} \cdot 7 \mathrm{H}_{2} \mathrm{O}, 0.5 ; \mathrm{NaCl}, 5$. Flasks were shaken at $\mathrm{I} 20 \mathrm{rev} . / \mathrm{min}$ on a reciprocating shaker with $8 \mathrm{~cm}$ stroke for 3 and 5 days at $28^{\circ} \mathrm{C}$.

Enzyme preparations. Culture broths were filtered through Toyo no. 2 filter papers (Toyo Roshi Kaisha, Osaka, Japan) and the filtrates were then centrifuged at $8000 \mathrm{~g}$ for $\mathrm{I}$ min. The supernatant fluids were used as enzyme preparations.

L-Asparaginase assay. A reaction mixture containing $0.8 \mu \mathrm{mol}$ of $\mathrm{L}$-asparagine, $10 \mu \mathrm{mol}$ of tris(hydroxymethyl)aminomethane- $\mathrm{HCl}$ buffer $(\mathrm{pH} 7 \cdot 2)$ and an enzyme preparation in a total volume of $0.1 \mathrm{ml}$ was incubated at $37^{\circ} \mathrm{C}$ for $30 \mathrm{~min}$. The reaction was stopped by the addition of $3.7 \mathrm{ml}$ of $0.008 \mathrm{M}$-trichloroacetic acid. A blank test, in which L-asparagine was added after the addition of trichloroacetic acid, was run for each experiment. Twenty minutes after the addition of $0.2 \mathrm{ml}$ of Nessler's reagent (Wako Pure Chemicals, Osaka, Japan), with incubation at $\mathrm{I} 5$ to $20^{\circ} \mathrm{C}$ the extinction at $450 \mathrm{~nm}$ was measured with a Shimad$\mathrm{zu}$ Bausch-Lomb Spectronic 20 colorimeter in a $\frac{1}{2}$ in cell. The amount of ammonia liberated from L-asparagine was determined from the difference in the extinctions of experimental and blank reaction mixtures. One international unit (i.u.) of L-asparaginase is the amount which liberates I $\mu \mathrm{mol}$ of ammonia in I $\mathrm{min}$ in the above described reaction conditions.

\section{RESULTS AND DISCUSSION}

Formation of L-asparaginase by Fusarium species. Out of 50 strains of Fusarium species, 47 strains formed more than $0 \cdot I$ i.u. of extracellular L-asparaginase/ml (Table I). There were many strains which produced high (more than 0.5 i.u. $/ \mathrm{ml}$ ) levels of L-asparaginase: Fusarium oxysporum, 9 out of 24 strains; $F$. solani, I 6 out of I 8 strains; $F$. caucasicum, the one strain; $F$. culmorum, I out of 2 strains; F. roseum, 2 out of 4 strains. Several species, such as $F$. oxysporum IFO5264, 933I, F. oxysporum f. lini IFO5880, F. oxysporum f. narcissi IFO5265, F. solani IFO5977, 7I 54, 7I63,8510, F. caucasicum IFO5979 and $F$. roseum IFO542I, formed extremely high levels of L-asparaginase activity (more than $2 \mathrm{i} . \mathrm{u} . / \mathrm{ml}$ ) in their culture filtrates.

It thus appears that the extracellular formation of L-asparaginase is one of the common properties within the genus Fusarium. 
Table 3. L-Asparaginase formation by Nectria species after 3 and 5 days of culture

Strain

Nectria cinnabarina IFO682 I

$N$. ditissima IF05995

N. elegans IFO7I 87

$N$. haematococca IFO6891

$N$. inventa IFO6306

$N$. pityrodes IFo6000

$\begin{array}{ll}\overbrace{\text { 3-day }}^{\text {Activity }} & \text { 5-day } \\ 0.03 & 0.09 \\ 0.14 & 1.20 \\ 0.91 & 1.06 \\ 0.94 & 1.20 \\ 0 & 0.05 \\ 0.74 & 0.92\end{array}$

Table 4. L-Asparaginase formation by Gibberella species after 3 and 5 days of culture

Strain

Gibberella fujikuroi IFO5268

G. fujikuroi IFO6349

G. fujikuroi 1 FO6 356

G. fujikuroi ${ }_{1 F 06603}$

G. fujikuroi IFO6604

G. fujikuroi IFO6605

G. fujikuroi 1 IFO6606

G. fujikuroi $1 \mathrm{FO} 6607$

G. lateritium $\mathrm{IFO} \mathrm{I} 88$

G. lateritium f. cerealis $\mathrm{IFO} 7704$

G. lateritium f. mori IFO7705

G. zeae $1 \mathrm{FO} 4474$

G. zeae IFO5269

G. zeae IF06608

G. zeae IFO7I60

G. zeae IFO7520

G. zeae IFo7772

G. zeae IFO8640

$\begin{array}{ll}\text { 3-day } & \text { 5-day } \\ 0.02 & 0.03 \\ 0 & 0.06 \\ 0 & 0.32 \\ 0 & 0 \\ 0.09 & 0.15 \\ 0 & 0.08 \\ 0 & 0 \\ 0.02 & 0.09 \\ 0 & 0 \\ 0.03 & 0.41 \\ 0 & 0.15 \\ 0.02 & 0.14 \\ 0 & 0.23 \\ 0.03 & 0.46 \\ 0 & 0.60 \\ 0 & 0.37 \\ 0 & 0 \\ 0.03 & 0.05\end{array}$

Formation of L-asparaginase by Fusarium-related species. There are several ascomycete genera, Hypomyces, Nectria and Gibberella, which have a Fusarium state in the imperfect cycle. Species of these genera have been examined to see whether they produce extracellular L-asparaginase or not.

In Table 2 the formation of L-asparaginase by Hypomyces species is shown. Hypomyces haematococcus IFO5980, $H$. solani f. mori IF07707, 7708 and $H$. solani f. xanthoxyli IFO 7709 , 77 Io are known to have a Fusarium asexual state. These species formed a high level of extracellular L-asparaginase. On the other hand, H. aurantius IF06847, 6890, 7773, H. rosellus IFO69I I and $H$. trichothecoides IF06892--all species with imperfect states not of the Fusarium type - rarely formed L-asparaginase.

Table 3 indicates the extracellular formation of L-asparaginase by Nectria species. Those species having a Fusarium or related imperfect state, such as Nectria ditissima IF05995, $N$. elegans IFO 7I87, $N$. haematococca IFO689I and $N$. pityrodes IFO6000, formed extracellular L-asparaginase, while those having no Fusarium state, such as $N$. cinnabarina IFo682 I and $N$. inventa IFO 6306, did not. Thus the ability of species of Hypomyces and Nectria to form extracellular L-asparaginase is closely related to whether they have a Fusarium state or not.

Gibberella species are also known to have a Fusarium state, but their ability to form Lasparaginase was small, as shown in Table 4 . 
These results show that the occurrence of a certain enzyme may reflect the taxonomy of micro-organisms. We understand that mere knowledge of enzyme activities solves no taxonomic problems, and that the use of enzyme activities in taxonomic keys sometimes presents problems. However, the accumulation of knowledge of enzyme activities and properties may give some hints in classifying interrelationships among micro-organisms and in solving problems of evolution of micro-organisms.

The L-asparaginase of Fusarium species suppresses the growth of $6 \mathrm{C}_{3} \mathrm{HED}$ lymphosarcoma in mice. Its enzymatic properties and antitumour activities will be reported elsewhere.

We thank Drs S. Tatsuoka, R. Takeda, and M. Isono of Central Research Division, Takeda Chemical Industries Ltd, for their continued interest and encouragement throughout the course of our work. We also thank Mr H. Ono, Miss H. Sotoma and Miss Y. Nakamura for their skilful technical assistance.

\section{REFERENCES}

AdAmson, R. H. \& Fabro, S. (1968). Antitumor activity and other biological properties of L-asparaginase. Cancer Chemotherapy Reports 25, 617-626.

arima, K., Sakamoto, T., Araki, C. \& Tamura, G. (1972). Production of extracellular L-asparaginases by microorganisms. Agricultural and Biological Chemistry 36, 356-36r.

$\mathrm{BACH}, \mathrm{D}$. (1928). Les conditions d'action de l'asparaginase de l'Aspergillus niger. Compte rendu hebdomadaire des séances de l'Académie des sciences $187,955-956$.

De-Angeli, L. C., Pocciari, F., Russi, S., Tonolo, A., Zurita, V. E., Ciaranfi, E. \& Perin, A. (1970). Effect of L-asparaginase from Aspergillus terreus on ascites sarcoma in the rat. Nature, London 225, 549550 .

Dox, A. W. (1909). The intracellular enzymes of lower fungi, especially those of Penicillium camemberti. Journal of Biological Chemistry 6, 46I-467.

Imada, A., Igarasi, S., Nakahama, K. \& Isono, M. (I973). Asparaginase and glutaminase activities of micro-organisms. Journal of General Microbiology (in the press).

Scheetz, R. W., Whelan, H. A. \& Wriston, J. C., Jun. (1971). Purification and properties of an L-asparaginase from Fusarium tricinctum. Archives of Biochemistry and Biophysics 142, I 84-189.

Schmalfuss, K. \& Mothes, K. (1930). Über die fermentative Desamidierung durch Aspergillus niger. Biochemische Zeitschrift 221, I34-I 53.

Wriston, J. C., JUn. (1971). L-Asparaginase. In The Enzymes, 3rd edn, vol. IV, pp. IOI-12I. Edited by P. D. Boyer. New York and London: Academic Press. 